\title{
Utilization of L-methionine and production of methanethiol by bacteria isolated from raw milk Camembert cheese
}

\author{
D. HEMME and J. RICHARD \\ INRA, Laboratoire de Microbiologie laitière - 78350 Jouy-en-Josas, France
}

\section{Summary}

Eighty bacterial strains isolated from the surface of Camembert cheeses prepared with raw milk were tested for their capacity to produce methanethiol. With the exception of two strains identified as Straphylococcus xylosus, the only strains able to produce methanethiol from L-methionine in sufficient quantities to be of possible technological interest were orange coryneform bacteria related to Brevibacterium linens. Only strains able to produce methanethiol could develop on minimal medium containing L-methionine or $\alpha$-ketobutyrate as carbon source. This character may be used as a screening test when studying surface cheese flora. These results are discussed in relation to the role of $B$. linens in the ripening process of cheeses with surface flora.

Key words : Brevibacterium linens - Aromatic sulfur compounds - Cheese ripening flora - Screening test.

\section{Résumé}

Utilisation de la L-méthionine et production de méthane-thiol par des bactéries isolées de Camembert fabriqué avec du lait cru

Quatre-vingt souches bactériennes isolées de la surface de Camemberts fabriqués avec du lait cru ont été testées pour leur aptitude à produire du méthanethiol. Mises à part deux souches identifiées à Staphylococcus xylosus, les seules souches capables de produire, à partir de L-méthionine, du méthane-thiol en quantité suffisante pour présenter un intérêt technologique éventuel étaient des bactéries corynéformes formant des colonies oranges et apparentées à Brevibacterium linens. Seules les souches productrices de méthane-thiol étaient capables de se développer sur un milieu minimal dont la source de carbone était soit la L-méthionine, soit l' $\alpha$-cétobutyrate. Ce caractère permet de les détecter facilement parmi l'ensemble des autres bactéries se développant à la surface des fromages.

Mots clés : Brevibacterium linens - Composés d'arôme soufrés - Flore d'affinage des fromages - Méthodes de tri. 


\section{Introduction}

In France, certain surface-mould ripened soft cheeses, e.g. Camembert prepared from raw milk, exhibit a characteristic " garlic " aroma (ADDA et al., 1978). Chemical analyses have shown that this property could be attributed to the presence of compounds containing one or several sulfur atoms (ADDA et al., 1978 ; HeMme et al., 1982). Many are formed from condensation reactions, probably purely chemical, in which methanethiol $\left(\mathrm{CH}_{3} \mathrm{SH}\right)$ is involved. This compound arises from the degradation of methionine by various microorganisms in cheese flora (DUMONT and ADDA, 1978 ; MANNING, 1979). There is a large number of microorganisms which can produce methanethiol from methionine (HeMme et al., 1982 ; Kadota and IsHIDA, 1972). Some of them are normally present in Camembert cheeses. They are members of the genera Penicillium, Geotrichum, yeasts (SCHMIdT and LAMBERET, 1981) and bacteria (RICHARD and ZADI, 1983). Bacteria developing on the surface of Camembert cheeses prepared from raw milk form a complex flora which includes species of the genera Micrococcus and Staphylococcus (S. xylosus), coryneform bacteria, enterobacteria (primarily Hafnia alvei) and bacteria whose characteristics are close to those of the genus Moraxella (RICHARD and ZADI, 1983 ; RICHARD, 1984).

All these microorganisms are present at a high density (greater than $10^{7} / \mathrm{g}$ of rind). ZADI (1981) observed that most orange coryneform strains were capable of using methionine as sole carbon source in minimal medium. In parallel, an odor reminiscent of methanethiol was released from the cultures. This compound was probably produced from methionine by a mechanism analogous to that described in the case of other microorganisms (HEMme et al., 1982). This metabolic pathway includes $\alpha$-ketobutyrate as intermediate, which is in fact the substrate used by the bacteria.

The aim of the present investigation was to establish the possible correlation between growth in the presence of methionine or $\alpha$-ketobutyrate as sole energy source and the production of methanethiol from methionine by bacterial strains predominating in the flora of Camembert cheeses produced from raw milk.

\section{Materials and methods}

\section{A. Origin and maintenance of strains}

Eighty bacterial strains were isolated from the dominant surface flora of Camembert cheeses manufactured from raw milk in 5 Normandy dairies. After purification, the strains were maintained on buffered nutrient agar (BNA) (RICHARD and ZADI, 1983). They were reisolated on the same medium just prior to use. 


\section{B. Utilization of L-methionine and $\alpha$-ketobutyrate}

Growth of the strains at $25^{\circ} \mathrm{C}$ on agar medium was followed for 3 weeks and estimated by comparison to controls on medium without methionine or $\alpha$-ketobutyrate. The agar medium used was a minimal medium (STANIER et al., 1966) supplemented with vitamins as described by BousFIELD (1972), riboflavin $(5 \mu \mathrm{g} / \mathrm{ml})$ and pyridoxal phosphate $(7.5 \mu \mathrm{g} / \mathrm{ml})$. Aqueous solutions of L-methionine and $\alpha$-ketobutyrate $(50 \mathrm{~g} / \mathrm{l})$ were sterilized by filtration (pore size $200 \mathrm{~nm}$ ) and added to the medium so as to abtain final concentrations of $2 \mathrm{~g} / 1$ in the agar. The medium was distributed in square compartmented dishes at $2 \mathrm{ml}$ per compartment. A multipoint inoculator was used with an aqueous suspension of a fragment of a colony.

\section{Bacterial cultures for determining methanethiol production}

Two methods of cell production were tested in parallel. Bacteria were first grown at $25^{\circ} \mathrm{C}$ with shaking (Erlenmeyer flasks) in Nutrient Broth (N.B., Difco). After sufficient growth (medium cloudy) a $250 \mathrm{ml}$ flask containing $50 \mathrm{ml}$ of the same medium with $0.1 \%$ L-methionine (Sigma, St. Louis, USA) was inoculated at $0.1 \%$ and incubated at $25^{\circ} \mathrm{C}$ with shaking. Cultures on solid medium were obtained by streaking $0.2 \mathrm{ml}$ of nutrient broth on the surface of BNA, also containing $0.1 \%$ L-methionine. Incubation was also performed at $25^{\circ} \mathrm{C}$ for up to 11 days depending the growth rate of individual isolates. This was appreciated visually by the amount of slime on the surface of the agar.

\section{Methanethiol production capacity of resting cells}

Cells growing in liquid medium were harvested by centrifugation at $12,000 \mathrm{~g}$ at $4^{\circ} \mathrm{C}$ when the $\mathrm{pH}$ of the cultures increased to at least 8 , except in kinetic experiments, where cells were harvested at different $\mathrm{pH}$ values. The pellet was suspended in Tris- $\mathrm{HCl}$ buffer, $\mathrm{pH} 8$, in order to obtain an $\mathrm{A}_{650}$ of 1 .

Bacteria growing on the surface of agar were recovered by scrubbing it with a spatula after 1 to 11 days of incubation, depending on growth rate. They were suspended in Tris buffer $50 \mathrm{mM} \mathrm{pH} 8.0$ and adjusted to $\mathrm{A}_{650}=1$.

The test was carried out as previously described (LAAKSO and NURMIKKo, 1976 ; FERCHICHI et al., 1985), with incubation shortened from $1 \mathrm{~h}$ to $30 \mathrm{~min}$. The specific methanethiol production capacity (sMTPC) of the cells was expressed in nkat/g dry wt (nmol of methanethiol produced from methionine per second per $\mathrm{g}$ dry weight of cells in the specific conditions of the assay).

\section{Results}

\section{A. Relationship between physiological status of the cells and methanethiol production}

Methanethiol production in standardized conditions by cells obtained from surface colonies was higher than that by cells from shaken liquid 


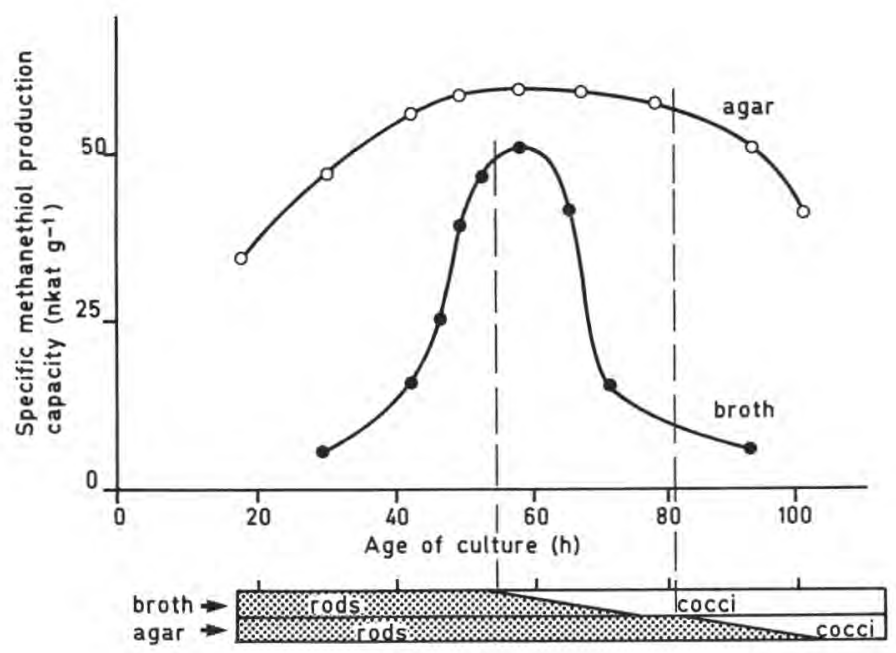

Fig. 1

Comparative production of methanethiol by resting cells of strain CNRZ 9.18 of Brevibacterium linens obtained from cultures on agar $(0)$ and in liquid broth $(\bullet)$ and proportion of rod and coccoid forms. Vertical lines indicate the moment of apparition of coccoid forms.

Production comparée de méthanethiol par des cellules non proliférantes de Brevibacterium linens CNRZ 918 issues de cultures sur gélose (O) ou en bouillon (•) et proportion des formes bâtonnet et coque. Les lignes verticales indiquent l'apparition de la forme coque.

medium (fig. 1). Moreover, the specific methanethiol production capacity (SMTPC) as a function of culture age was higher and more stable for cells from agar medium than from liquid broth. Light microscopic observations showed that cells remained rod shaped for more than 5 days when they developed on agar, whereas coccoid forms appeared after 2 days in broth.

B. Utilization of L-methionine and $\alpha$-ketobutyrate, and methanethiol production by non-proliferating cells

It was essentially the coryneform bacteria similar to $B$. linens which could use L-methionine (called Met + ) as sole energy source (table 1). In addition, all the strains capable of using L-methionine were also capable of growing with $\alpha$-ketobutyrate as sole energy source.

Most strains using L-methionine and $\alpha$-ketobutyrate as sole energy source also produced methanethiol when grown in complex nutrient medium containing L-methionine. All these bacteria formed orange colonies on agar. The non-proliferating cells used in the methanethiol production test were thus capable of carrying out the gamma demethiolation of L-methionine in the reaction mixture (KreIss and Hession, 1973). Two orange strains identified as Staphylococcus xylosus were also capable of producing methanethiol in 


\section{Table 1 - Tableau 1}

Growth of 80 bacteria isolated from raw milk Camembert on minimal medium containing L-methionine or a-ketobutyrate, and methanethiol production

from L-methionine

Croissance des micro-organismes isolés de Camembert de lait cru sur milieu minimal contenant de la L-méthionine ou de l'a-cétobutyrate et production de méthanethiol à partir de la L-méthionine

\begin{tabular}{|c|c|c|c|c|}
\hline \multirow{3}{*}{ Bacterial strains } & \multirow{3}{*}{$(\mathrm{N})$} & \multicolumn{3}{|c|}{ Number of strains } \\
\hline & & \multicolumn{2}{|c|}{ Growing from } & \multirow{2}{*}{$\begin{array}{l}\text { Producing } \\
\text { methanethiola }\end{array}$} \\
\hline & & $\begin{array}{c}\text { L-methionine } \\
(\text { Met }+)\end{array}$ & $\begin{array}{c}\alpha \text {-keto- } \\
\text { butyrate }\end{array}$ & \\
\hline $\begin{array}{l}\text { Coryneform bacteria } \\
\text { Orange colonies } \\
\text { White colonies } \\
\text { Yellow colonies }\end{array}$ & $\begin{array}{r}(51) \\
(29) \\
(5) \\
(17)\end{array}$ & $\begin{array}{c}26 \mathrm{~b} \\
0 \\
0\end{array}$ & $\begin{array}{c}26 \mathrm{~b} \\
0 \\
0\end{array}$ & $\begin{array}{r}24 \\
0 \\
0\end{array}$ \\
\hline $\begin{array}{l}\text { Staphylococcus xylosus } \\
\text { Enterobacteria } \\
\text { Moraxella spp. }\end{array}$ & $\begin{array}{r}(12) \\
(7) \\
(10)\end{array}$ & $\begin{array}{l}1 \mathrm{c} \\
0 \\
0\end{array}$ & $\begin{array}{l}1 \\
0 \\
0\end{array}$ & $\begin{array}{l}2 \mathrm{c} \\
0 \\
1\end{array}$ \\
\hline \multicolumn{5}{|c|}{$\begin{array}{l}\text { a : specific methanethiol producing capacity higher than } 10 \mathrm{nkat} / \mathrm{g} \text { dry wt. } \\
\mathrm{b}: \text { only } 28 \text { strains tested. } \\
\mathrm{c}: \text { including the strain using L-methionine and } \alpha \text {-ketobutyrate. } \\
\mathrm{N}: \text { number of strains for each type. }\end{array}$} \\
\hline
\end{tabular}

complex medium, although they did not grow in the minimal medium containing L-methionine. No coryneform strain forming white colonies was capable of producing methanethiol. The small number of strains tested, however, does not enable a valid generalization to be advanced. Only one strain of Moraxella was both capable of using methionine and $\alpha$-ketobutyrate as sole source of carbon and to produce significant amount of methanethiol.

\section{Determination of methanethiol production capacity (MTPC)}

Using the modified test, a satisfactory reproducibility $(<15 \%)$ was obtained. Specific production (production of methanethiol/g of dry weight of cells) by the orange coryneform strains varied according to the strain when they were grown on nutrient agar (fig. 2). There was no clearcut correlation between the growth rate of a strain and its specific production of methanethiol capacity. However it can be noted that no slow growing strains (5 days or more) has a very high production. 


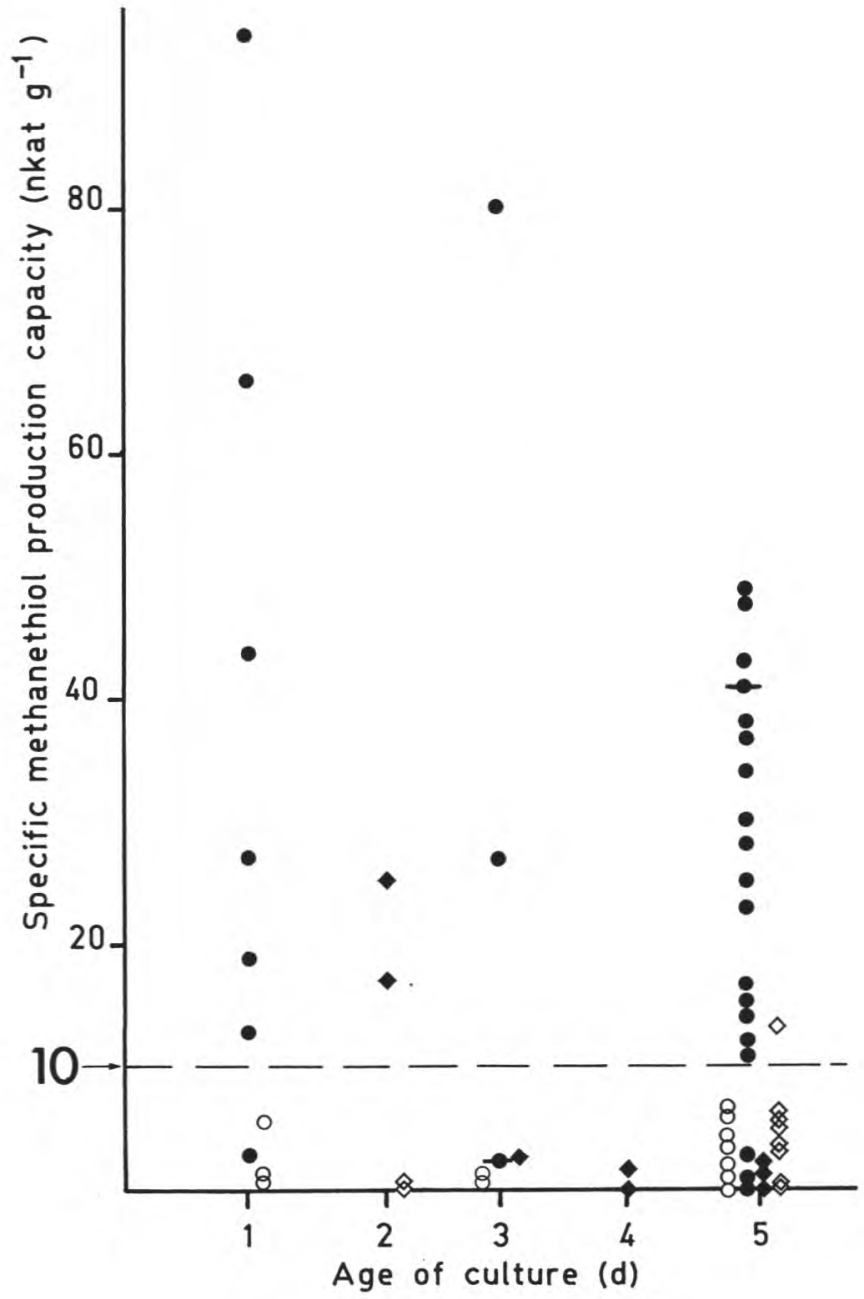

Fig. 2

Specific production of methanethiol (MMTPC) from L-methionine by nonproliferating cells of 73 bacterial strains isolated from the Camembert cheese made from raw milk.

Bacteria were grown on nutrient agar. Culture age (abcissa) is that corresponding to the appearance of a bacterial slime. The symbols represent orange coryneform bacteria Met+ $(\bullet)$ and Met $-(\rightarrow)$, yellow and white coryneform bacteria (0), Staphylococcus xylosus $(\bullet)$ and Moraxella spp. $(\diamond)$. Strains without activity are represented only by one point.

Production spécifique $(S M T P C)$ de méthanethiol à partir de L-méthionine par les cellules non proliférantes de 73 souches bactériennes isolées de Camembert fabriqué avec du lait cru.

Les bactéries étaient cultivées sur gélose nutritive. L'âge de la culture (abscisse) est celui qui correspond à l'apparition d'un tapis bactérien. Les symboles représentent les bactéries corynéformes orange Met+ $(\bullet)$ et Met- $(-)$, les bactéries corynéformes jaunes et blanches (0), Staphylococcus xylosus $(\diamond)$ et Moraxella spp. $(\diamond)$. Les souches sans activité sont représentées par un seul point. 


\section{Discussion}

With the exception of two strains of S. xylosus and one of Moraxella, the best producers of methanethiol were the orange coryneforms, using the chemical detection with DTNB. The negative strains should have been found to be " methanethiol producers " by a more sensitive technique such as gas chromatography (LAW and SHARPE, 1978). However it is reasonable to consider that only strains with high activity (e.g. $>10 \mathrm{nkat} / \mathrm{g}$ ) can play a role in the technology of cheeses presenting a strong garlic odor, as is the case for Camembert.

The uptake of L-methionine by cells could not be involved to explain this difference in SMTPC between bacteria from surface and from broth cultures as it has been shown that rods and cocci have the same uptake (FeRcHICHI et al., 1986). In addition, inhibition by methanethiol itself is probably more important in broth (PEZET and PONT, 1980 ; Ferchichi, 1984).

On the other hand, the higher level of aerobiosis in plates than in broth would explain the phenomenon but this may be rejected as a significant factor, since it has been shown the sMTPC is higher with $25 \%$ saturation of dissolved oxygen in the medium than with $50 \%$ (FERCHICHI et al., 1984-1986).

None of the white coryneform bacteria isolated from Camembert cheese were methanethiol producers. This does not imply that it is a trait of this group since two white coryneform strains (CNRZ 911 and 912, respectively NCDO 2048 and 2049) obtained from the Food and Research Institute (Shinfield, Reading, England) were found to be methanethiol producers (SHARPE et al., 1977). However these strains were of skin origin and had an optimal growth temperature higher than that of cheese coryneform $\left(37^{\circ} \mathrm{C}\right.$ vs $\left.25^{\circ} \mathrm{C}\right)$.

The fact that $\alpha$-ketobutyrate can replace methionine for growth suggests that this compound may also be an intermediate in methionine catabolism by orange cheese coryneform bacteria as described for other microorganisms investigated (Hemme et al., 1982).

The utilization of methionine - or $\alpha$-ketobutyrate which is apparently equivalent - as the sole energy source is a simple test to demonstrate the capacity of isolated bacteria to produce methanethiol. It has been used on a large scale for investigating the differences between seasons and manufacturers in the flora of Camembert cheese (RICHARD, 1984). Nevertheless, positive strains must be tested in terms of the intensity of this capacity. This could be facilitated by the development of a simple, miniaturized and reproducible method, applicable to investigations in series.

\section{Acknowledgments}

The authors thank Evelyne Arrouy, Nicole Pamboukdjian and Jean-Jacques Gratadoux for the assistance during this work. 


\section{Références bibliographiques}

AdDA J., Roger S. and Dumont J.P., 1978. Some recent advances in the knowledge of a cheese flavor. In Flavor of foods and beverages. Chemistry and technology, Eds Charalambus G. \& Inglett C.E., p. 65-74, London, Academic Press.

Bousfield I.J., 1972. A taxonomic study of some coryneform bacteria. J. Gen. Microbiol., $71,441-455$.

Dumont J.P. and AdDA J., 1978. Flavour formation in dairy products. In Progress in flavour research, Eds Land D.G. \& Nursten H.A., p. 245-262. Essex, England, Applied Science Publishers.

Ferchichi M., 1984. Production de méthane-thiol à partir de L-Méthionine par Brevibacterium linens CNRZ 918. Induction, caractérisation, nature des systèmes enzymatiques. Thesis, University of Paris VII, France.

Ferchichi M., Hemme D., Nardi M. and Pamboukdjian N., 1985. Production of methanethiol by Brevibacterium linens CNRZ 918. J. Gen. Microbiol., 131, 715-723.

Ferchichi M., Hemme D. and BouillanNe C., 1986. Influence of oxygen and $\mathrm{pH}$ on methaniol production from L-methionine by Brevibacterium linens (CNR 918. Appl. Environ. Microbiol., 51 (4) (in press).

Hemme D., Bouillanne C., Metro F. and Desmazeaud M.J., 1982. Microbial catabolism of aminoacids during cheese ripening. Sci. Aliments, 2, 113-123,

KADOTA H. and IsHIDA Y., 1972. Production of volatile sulfur compounds by micro-organisms. Ann. Rev. Microbiol., 26, 127-138.

KREISS W. and Hession C., 1973. Isolation and purification of L-methionine $\alpha$-deamino- $\gamma$ mercaptomethane-lyase (L-methioninase) from Clostridium sporogenes. Cancer Res., 33, $1862-1865$.

LAAKso S. and Nurmikко V., 1976. A spectrophotometric assay for demethiolating activity. Anal. Biochem., 72, 600-605.

LAW B.A. and SHARPE M.E., 1978. Formation of methanethiol by bacteria isolated from raw milk and Cheddar cheese. J. Dairy Res., 45, 267-275.

Manning D., 1979. Chemical production of essential Cheddar flavour compounds. J. Dairy Res., 46. 531-537.

PEzET R. and PonT V., 1980. Methanethiol : a morphogenetic factor produced from Lmethionine by Phomopsis viticola Sacc. Can. J. Microbiol, 26, 336-362.

RichaRD J., 1984. Evolution de la flore microbienne à la surface des Camemberts fabriqués avec du lait cru. Lait, 64, 496-520.

RICHARD J. et ZADI H., 1983. Inventaire de la flore bactérienne dominante des Camemberts fabriqués avec du lait cru. Lait, 63, 25-42.

Sharpe M.E., LAw B.A., Philipps S.A. and Pitcher D.G., 1977. Methanethiol production by coryneform bacteria : strains from dairy and human skin sources and Brevibacterium linens. J. Gen. Microbiol., 101, 345-349.

Schmidt J.L. et Lamberet G., 1981. Les levures du fromage de Camembert : principales espèces et possibilités d'intervention au cours de l'affinage. In Adv. Biotechnol., Vol. 2, Fuels, chemical, foods and waste treatment, p. 485-490. Toronto, Canada : Pergamon Press.

Stanier R.Y., Palleroni N.J. and Doudoroff M., 1966. The aerobic Pseudomonas : a taxonomic study. J. Gen. Microbiol., 43, 1259-1271.

Zadi H., 1981. Etude de la flore bactérienne non lactique des Camemberts fabriqués de façon traditionnelle. Thesis University of Paris XI, France. 